\title{
The effect of sex and age at slaughter on the physicochemical properties of baby-beef meat
}

\section{Dejan Marenčić1, Ante Ivanković́2 Lidija Kozačinski ${ }^{3 *}$, Maja Popovićc and Željka Cvrtila ${ }^{3}$}

\author{
${ }^{1}$ College of Agriculture at Križevci, Križevci, Croatia \\ ${ }^{2}$ Department of Animal Science and Technology, Faculty of Agriculture, University of Zagreb, Zagreb, Croatia \\ ${ }^{3}$ Department of Hygiene, Technology and Food Safety, Faculty of Veterinary Medicine, University of Zagreb, \\ Zagreb, Croatia \\ ${ }^{4}$ Department of Biology, Faculty of Veterinary Medicine, University of Zagreb, Zagreb, Croatia
}

\begin{abstract}
MARENČIĆ, D., A. IVANKOVIĆ, L. KOZAČINSKI, M. POPOVIĆ, Ž. CVRTILA: The effect of sex and age at slaughter on the physicochemical properties of baby-beef meat. Vet. arhiv 88, 101-110, 2018.
\end{abstract}

\section{ABSTRACT}

The aim of this study was to determine the effect of sex and age at slaughter on the physicochemical properties and quality of Simmental baby-beef. The research was conducted on 1,200 livestock, of which 600 were male and 600 female. Male cattle were slaughtered at the age of 13 to 14 months, 15 to 16 months and 17 to 18 months, while female cattle were slaughtered at the age of 12 to 13 months, 14 to 15 months and 16 to 17 months. Physicochemical properties associated with the quality of meat ( $\mathrm{pH}, \mathrm{EC}$ and meat colour parameters) were measured 24 hours post mortem on the $\mathrm{m}$. longissimus dorsi. While sex significantly influenced the physicochemical properties associated with the quality of baby-beef $(\mathrm{P}<0.001)$, different age at slaughter had little effect on the physicochemical properties associated with the quality of meat $(\mathrm{P}>0.05)$, thus indicating the possibility of increasing the slaughter age of male and female Simmental cattle up to 18 and 17 months respectively, without a substantial negative impact on the physicochemical properties associated with the quality of baby-beef.

Key words: sex; age; slaughter; physicochemical properties; baby-beef

\section{Introduction}

Consumers are placing more and more emphasis on the quality of food and generally form their impressions on meat quality on the basis of its colour. It has long been believed that dark meat and meat striped with yellow-coloured fat tissue comes from old and sick

\footnotetext{
${ }^{*}$ Corresponding author:
}

Prof. dr. sc. Lidija Kozačinski, DVM, Department of Hygiene, Technology and Food Safety, Faculty of Veterinary Medicine University of Zagreb, Heinzelova 55, Zagreb 10 000, Croatia, Phone.: +385 12390 190, Mob.: +385 091 2390 151, E-mail: klidija@vef.hr

ISSN 0372-5480

Printed in Croatia 
animals (MUCHENJE et al., 2009). Great emphasis, during the production of babybeef, is therefore placed on the control and sustainability of meat colour. Since dark meat represents one of the leading problems in the sale of baby-beef and causes the meat industry millions in losses, it has been the subject of numerous studies.

The dynamics of glycolysis and $\mathrm{pH}$ changes in muscles influence the quality of meat in two ways. If the $\mathrm{pH}$ falls quickly, the meat will be pale, soft and exudative (PSE), while a slow and incomplete drop of $\mathrm{pH}, 24$ hours after slaughter, causes dry, firm and dark meat (DFD). The incidence of PSE meat in young cattle is very rare. PAGE et al. (2001) stated that according to the 1997 United States Department of Agriculture (USDA) standards, all beef carcasses with $\mathrm{pH}_{24}$ higher than 5.80 are classified as dark. Dark meat has a low $\mathrm{L}^{*}$ value, which represents lightness and varies from 0 (black) to 100 (white). The water holding capacity (WHC) is another important feature associated with meat quality. It refers to the ability of meat to retain water post-mortem. This occurs spontaneously and under the influence of external factors, such as gravity or heat treatment (HUFFLONERGAN, 2005). Electrical conductivity (EC) is the measure of the ability to bind or lose water (BYRNE et al., 2000). PAGE et al. (2001) reported that electrical conductivity measures the conductivity of electrical current through the muscle tissue and is associated with the amount of unbound water in the muscles.

The quality of meat is determined by a variety of endogenous (breed, sex, age at slaughter) and external factors (fattening technology, transport, slaughter, meat storage conditions, etc.) (RENAND et al., 2001; ČUBIĆ et al., 2011; MARENČIĆ et al., 2012). A significant number of studies have indicated that breed, sex, age at slaughter and nutrition affect the weight gain of young cattle, and carcass yield (FRENCH et al., 2001; VESTERGAARD et al., 2000). Even though many studies have examined the effect of sex and age at slaughter on the colour of meat (MURAMOTO et al., 2003; PLESSIS and HOFFMAN, 2007; MOJTO et al., 2009; SARGENTINI et al., 2010), they have primarily focused on dairy and older beef breeds (over 18 months of age).

The aim of this study was to determine the impact of the age at slaughter and sex on the physicochemical properties and quality of Simmental breed meat.

\section{Materials and methods}

Experimental animals. The biological part of our research was carried out on 1,200 randomly selected Simmental livestock, 600 of whom were male and 600 female. The fattening of young cattle was carried out on three fattening farms. Young cattle were kept in large covered pens, each holding about 10 young cattle and measuring $61 \mathrm{~m}^{2}$ in size. The young cattle were fattened by applying a common fattening technology. They were fed once a day, following a total mixed ration (TMR) method. The meals provided were uniform throughout the year and available to the cattle at will. An average TMR meal consisted of $6.5 \mathrm{~kg}$ of corn silage (30\% dry matter), $5.5 \mathrm{~kg}$ of high moisture corn ( 


\section{Marenčić et al.: Influence of sex and age on physicochemical properties of baby-beef meat}

$70 \%$ dry substance), $650 \mathrm{~g}$ of straw ( $~ 35 \%$ dry matter) and $1.4 \mathrm{~kg}$ of concentrated feed containing $34 \%$ crude protein. Each meal had an average nutritional value of $\sim 76 \mathrm{MJ} / \mathrm{kg}$ of $\mathrm{ME}$ and $950 \mathrm{gr} / \mathrm{kg}$ of crude protein. With regard to the slaughter age, male and female cattle were divided into three groups. Male cattle were slaughtered at an age ranging from 13 to 14 months $(n=200), 15$ to 16 months $(n=200)$ and 17 to 18 months $(n=200)$, while female cattle were slaughtered at an age ranging from 12 to 13 months $(n=200)$, 14 to 15 months $(n=200)$ and 16 to 17 months $(n=200)$. In accordance with applicable legislation (ANON., 2005), young cattle were transported to the slaughterhouse in the early morning and the transport itself lasted about 265 minutes. The slaughter and processing of carcasses were performed in the export slaughterhouse of PIK Vrbovec (HR 10). The slaughter was carried out according to the standard procedure. Young cattle were first rendered unconscious using a captive bolt pistol (Schermer), whose pointed bolt penetrated their brain. After the cattle were stunned, their blood vessels were severed at the brachiocephalic artery (truncus brachiocephalicus). The cattle were exsanguinated in a hanging position. After the outflow of blood, they were decapitated and their carcasses processed according to the standard procedure (ANON., 2004). Processed carcasses were placed in cold storage, at a temperature of $4{ }^{\circ} \mathrm{C}$. All procedures used in this research were in compliance with the European guidelines for the care and use of animals in research (Directive 2010/63/EC).

Slaughter characteristic of meat. The company Agroinspekt d.o.o. provided us with relevant data on the slaughter characteristics of carcasses (slaughter weight, degree of fatty tissue coverage) and we calculated the net daily gain ourselves (weight of chilled halves/age $\times 1000$ ).

Technological properties of meat. Parameters of colour, electrical conductivity and $\mathrm{pH}$ related to meat were monitored at the anatomical position of the area at the intersection of the $m$. longissimus dorsi, at the height of the $6^{\text {th }}$ and $7^{\text {th }}$ ribs, on the right half of each carcass. The monitored parameters (colour, $\mathrm{pH}$ and electrical conductivity) were measured 24 hours post-mortem, namely after the bloom time (80 minute long exposure of MLD to aeration), when the colour of the meat had stabilized. The colour of the meat was determined in accordance with the CIE standard (Comission Internationale de l'Eclairage), using a Minolta CR-410 Chroma Meter (Minolta Co., Ltd., Japan) with a $50 \mathrm{~mm}$ measuring aperture for a colour-opponent space, with the dimensions $\mathrm{L}^{*}$ (lightness) $\mathrm{a}^{*}$ (redness) $\mathrm{b}^{*}$ (yellowness) $\mathrm{C}^{*}$ (chroma) and $\mathrm{h}^{*}$ (hue). The colour spectrum was determined using a standard D65 illuminant. The concentration of hydrogen ions $(\mathrm{pH})$ was measured with Eutech's CyberScan pH 310 instrument. Electrical conductivity was measured in millisiemens/cm using a LF-Control system device (Würthinger, Pettenbach, Austria).

We analysed the results obtained by monitoring the relevant quality parameters using the SAS statistical software (SAS Institute, 1999) and applying the GLM procedure. We used the ANOVA multivariate linear model to analyse the impact of sex and age 
D. Marenčić et al.: Influence of sex and age on physicochemical properties of baby-beef meat

at slaughter on the quality of meat, and Tukey's HSD test to determine the significance of differences between the examined groups. The classification of meat based on $\mathrm{pH}$ was performed in line with the recommendations published by PAGE et al. (2001), that consider all carcasses with a $\mathrm{pH}$ greater than 5.8 dry, firm and dark meat (DFD), while the levels of significance were determined by applying the Pearson's chi-squared test.

\section{Results}

Slaughter characteristics and technological properties. The significance of differences in the carcasses' slaughter characteristics (slaughter weight, net daily gain, degree of fatty tissue coverage) between the sexes and the quality of baby-beef meat ( $\mathrm{pH}$, EC and colour parameters: $\mathrm{L}^{*}, \mathrm{a}^{*}, \mathrm{~b}^{*}, \mathrm{C}^{*}$ and $\mathrm{h}^{*}$ ) are shown in Table 1.

Table 1. Descriptive statistics, significance of difference of carcass slaughter characteristics and quality of baby-beef, of male and female Simmental cattle

\begin{tabular}{|c|c|c|c|c|c|c|c|}
\hline Parameters & Sex & Mean & SD & SE & Min & Max & $\mathrm{CV}$ \\
\hline \multicolumn{8}{|c|}{ Carcasses' slaughter characteristics } \\
\hline \multirow{2}{*}{ Slaughter weight $(\mathrm{kg})$} & male & $363.05^{\mathrm{a}}$ & 40.71 & 1.65 & 207.00 & 456.00 & 11.21 \\
\hline & female & $272.23^{\mathrm{b}}$ & 21.42 & 0.69 & 195.00 & 392.00 & 7.87 \\
\hline \multirow{2}{*}{ Net daily gain $(\mathrm{kg})$} & male & $0.771^{\mathrm{a}}$ & 0.11 & 0.01 & 0.379 & 1.099 & 14.25 \\
\hline & female & $0.635^{\mathrm{b}}$ & 0.08 & 0.01 & 0.370 & 0.854 & 12.72 \\
\hline \multirow{2}{*}{$\begin{array}{l}\text { Degree of fatty tissue } \\
\text { coverage }\end{array}$} & male & $3.00^{\mathrm{a}}$ & 0.53 & 0.02 & 2.00 & 4.00 & 17.60 \\
\hline & female & $3.21^{\mathrm{b}}$ & 0.48 & 0.02 & 2.00 & 5.00 & 14.90 \\
\hline \multicolumn{8}{|l|}{ Quality of baby-beef } \\
\hline \multirow{2}{*}{$\mathrm{pH}$} & male & $5.61^{\mathrm{a}}$ & 0.13 & 0.01 & 5.45 & 6.73 & 2.24 \\
\hline & female & $5.57^{\mathrm{b}}$ & 0.07 & 0.01 & 5.41 & 6.28 & 1.27 \\
\hline \multirow{2}{*}{$\mathrm{EC}$} & male & $7.28^{\mathrm{a}}$ & 1.38 & 0.06 & 2.60 & 12.40 & 18.96 \\
\hline & female & $4.80^{\mathrm{b}}$ & 1.19 & 0.04 & 1.50 & 11.80 & 24.79 \\
\hline \multirow{2}{*}{$\mathrm{L}^{*}$} & male & $42.07^{\mathrm{a}}$ & 2.64 & 0.11 & 33.17 & 54.89 & 6.27 \\
\hline & female & $43.60^{b}$ & 2.06 & 0.07 & 35.44 & 51.45 & 4.71 \\
\hline \multirow{2}{*}{$a^{*}$} & male & $29.35^{\mathrm{a}}$ & 1.75 & 0.07 & 22.01 & 34.79 & 5.95 \\
\hline & female & $28.76^{\mathrm{b}}$ & 1.57 & 0.05 & 21.75 & 35.25 & 5.45 \\
\hline \multirow{2}{*}{$b^{*}$} & male & $11.45^{\mathrm{a}}$ & 1.33 & 0.05 & 6.74 & 14.78 & 11.64 \\
\hline & female & $11.71^{\mathrm{b}}$ & 1.00 & 0.03 & 7.74 & 15.03 & 8.53 \\
\hline \multirow{2}{*}{$C^{*}$} & male & $31.50^{\mathrm{a}}$ & 2.09 & 0.08 & 23.36 & 37.66 & 6.62 \\
\hline & female & $31.06^{\mathrm{b}}$ & 1.77 & 0.66 & 23.61 & 38.00 & 5.70 \\
\hline \multirow{2}{*}{$\mathrm{h}^{*}$} & male & $21.26^{\mathrm{a}}$ & 1.53 & 0.06 & 12.23 & 32.23 & 7.19 \\
\hline & female & $22.09^{b}$ & 1.21 & 0.04 & 10.52 & 29.46 & 5.47 \\
\hline
\end{tabular}

Values presented in the same column of the table that are labelled by different letters are significantly different $(\mathrm{P}<0.001)$. 
D. Marenčić et al.: Influence of sex and age on physicochemical properties of baby-beef meat

Table 2 shows the effect of sex on the baby-beef quality grades with regard to $\mathrm{pH}$ value. It is evident that sex has a significant effect on the incidence of DFD meat $(\mathrm{P}<0.001)$. The effects of age at slaughter on the carcasses' slaughter characteristics and the quality of baby-beef are shown in Table 3. In view of the slaughter characteristics of carcasses of young male cattle of different ages at slaughter, we found a significant difference for the recorded net daily gain and degree of fatty tissue coverage parameters $(\mathrm{P}<0.001)$, and only a negligible difference for the slaughter weight parameters $(\mathrm{P}>0.05)$. Table 4 shows that the age at slaughter had only a small effect on the quality classes of meat originating from young male and female cattle $(\mathrm{P}>0.05)$.

Table 2. Effect of sex on distribution of baby-beef quality grades (number of livestock, \%)

\begin{tabular}{|l|c|c|c|}
\hline Group & Desirable $\left(\mathrm{pH}_{24}<5.8\right)$ & DFD $\left(\mathrm{pH}_{24}>5.8\right)$ & Chi-test \\
\hline Male & $559(93.17 \%)$ & $41(6.83 \%)$ & $* * *$ \\
\hline Female & $584(97.33 \%)$ & $16(2.67 \%)$ & \\
\hline
\end{tabular}

DFD - dark, firm and dry meat; ***P<0.001

Table 3. Effect of age at slaughter on carcass slaughter characteristics and quality of baby-beef

\begin{tabular}{|c|c|c|c|c|c|c|c|c|}
\hline \multirow[b]{2}{*}{ Parameters } & \multicolumn{3}{|c|}{ Male } & \multirow[b]{2}{*}{ SE } & \multicolumn{3}{|c|}{ Female } & \multirow[b]{2}{*}{ SE } \\
\hline & $\begin{array}{l}13-14 \\
\text { month }\end{array}$ & $\begin{array}{l}15-14 \\
\text { month }\end{array}$ & $\begin{array}{l}17-14 \\
\text { month }\end{array}$ & & $\begin{array}{l}12-14 \\
\text { month }\end{array}$ & $\begin{array}{l}14-14 \\
\text { month }\end{array}$ & $\begin{array}{l}16-17 \\
\text { month }\end{array}$ & \\
\hline \multicolumn{9}{|c|}{ Carcass slaughter characteristics } \\
\hline \begin{tabular}{|l|} 
Slaughter \\
weight $(\mathrm{kg})$
\end{tabular} & 358.51 & 364.06 & 366.05 & 2.91 & $268.52^{\mathrm{a}}$ & $273.04^{\mathrm{b}}$ & $276.26^{\mathrm{b}}$ & 1.20 \\
\hline Net daily gain $(\mathrm{g} / \mathrm{kg})$ & $863.16^{\mathrm{a}}$ & $765.38^{\mathrm{b}}$ & $683.44^{\mathrm{c}}$ & 0.01 & $706.52^{\mathrm{a}}$ & $623.83^{\mathrm{b}}$ & $551.95^{\mathrm{c}}$ & 0.01 \\
\hline $\begin{array}{l}\text { Degree of fatty } \\
\text { tissue coverage }\end{array}$ & $3.14^{\mathrm{a}}$ & $2.94^{\mathrm{b}}$ & $2.97^{\mathrm{b}}$ & 0.04 & $3.26^{\mathrm{a}}$ & $3.20^{\mathrm{ab}}$ & $3.15^{\mathrm{b}}$ & 0.02 \\
\hline \multicolumn{9}{|c|}{ Quality of baby-beef meat } \\
\hline $\mathrm{pH}$ & 5.60 & 5.60 & 5.63 & 0.01 & 5.57 & 5.57 & 5.58 & 0.01 \\
\hline $\mathrm{EC}$ & 7.38 & 7.33 & 7.11 & 0.10 & 4.77 & 4.84 & 4.76 & 0.07 \\
\hline $\mathrm{L}^{*}$ & $42.59^{\mathrm{a}}$ & $42.06^{\mathrm{ab}}$ & $41.55^{b}$ & 0.19 & 43.76 & 43.71 & 43.58 & 0.12 \\
\hline$a^{*}$ & 29.22 & 29.43 & 29.35 & 0.13 & 28.61 & 28.81 & 28.91 & 0.09 \\
\hline $\mathrm{b}^{*}$ & 11.38 & 11.48 & 11.48 & 0.09 & 11.65 & 11.72 & 1.77 & 0.05 \\
\hline$C^{*}$ & 31.37 & 31.56 & 31.53 & 0.15 & 30.90 & 31.11 & 31.21 & 0.10 \\
\hline $\mathrm{h}^{*}$ & 21.30 & 21.26 & 21.23 & 0.11 & 22.10 & 22.03 & 22.14 & 0.07 \\
\hline
\end{tabular}


D. Marenčić et al.: Influence of sex and age on physicochemical properties of baby-beef meat

EC - electrical conductivity; Values presented in the same row of the table that are labelled with different letters are significantly different $(\mathrm{P}<0.05)$.

Table 4. Effect of slaughter age on distribution of baby-beef quality grades originating from both male and female cattle (number of livestock, \%)

\begin{tabular}{|l|c|c|c|c|}
\hline \multirow{3}{*}{ Sex } & Group & Desirable $\left(\mathrm{pH}_{24}<5,8\right)$ & $\mathrm{DFD}\left(\mathrm{pH}_{24}>5.8\right)$ & Chi-squared test \\
\hline \multirow{3}{*}{ Male } & $13-14$ month & $187(93.50 \%)$ & $13(6.50 \%)$ & \multirow{2}{*}{ NS } \\
\cline { 2 - 4 } & $15-16$ month & $188(94.00 \%)$ & $12(6.00 \%)$ & \multirow{2}{*}{ NS } \\
\cline { 2 - 4 } & $17-18$ month & $184(92.00 \%)$ & $16(8.00 \%)$ & \\
\hline \multirow{3}{*}{ Female } & $12-13$ month & $194(97.00 \%)$ & $6(3.00 \%)$ & \\
\cline { 2 - 5 } & $14-15$ month & $196(98.00 \%)$ & $4(2.00 \%)$ & \\
\cline { 2 - 4 } & $16-17$ month & $194(97.00 \%)$ & $6(3.00 \%)$ & \\
\hline
\end{tabular}

DFD - dark, firm and dry meat; NS - no significant difference P $>0.05$

\section{Discussion}

On the basis of the results of this research, we established the significant effect of sex on both the slaughter characteristics of carcasses and the quality of baby-beef $(\mathrm{P}<0.001)$. When we considered the slaughter characteristics of the carcasses, we observed that young male cattle had a significantly greater slaughter weight and larger net daily gain, while young female cattle had a significantly higher degree of fatty tissue coverage $(\mathrm{P}<0.001)$.

Regarding the quality of baby-beef, our results show that sex had a significant effect on both the quality and the colour of baby-beef $(\mathrm{P}<0.001)$. Several authors have stated that young female cattle typically produce halves with a higher degree of intramuscular fat (marbling), which in turn causes a higher $L^{*}$ and a higher $b^{*}$ value (WULF et al., 1997; PAGE et al., 2001; TATUM et al., 2007). Young female cattle in our research recorded significantly lower electrical conductivity $(\mathrm{EC})$ values than young male cattle $(\mathrm{P}<0.001)$. ALDAI et al. (2006) found that young cattle with a higher degree of intramuscular fat (marbling) showed a lower loss of water and had a lower EC value.

The results obtained in this study regarding the effect of sex on the baby-beef quality grades were consistent with the majority of other research (MOJTO et al., 2009; WULF et al., 1997; PAGE et al., 2001). Despite the more favourable incidence of DFD meat in both young male and female cattle, the results of this study also showed a significantly higher incidence of DFD meat in young males than in young female cattle $(\mathrm{P}<0.001)$. By comparing young male and female cattle, MOJTO et al. (2009) reported that young male cattle were physically more active during the night and therefore depleted their glycogen reserves, causing a higher final $\mathrm{pH}$ value and a higher incidence of DFD meat. In our opinion, the differences between the sexes in this research were primarily caused by differences in temperament, as well as the different response to stress that usually 


\section{Marenčić et al.: Influence of sex and age on physicochemical properties of baby-beef meat}

occurs immediately before the slaughter of animals. This conclusion was substantiated by previous studies that suggested that young male cattle are more prone to glycogen exhaustion before slaughter than females and castrated cattle, due to their irritable temperament and aggressive behaviour (MONIN, 2004; TATUM, 2006; MARENČIĆ et al., 2012). In comparison to cattle that were less excitable, TATUM et al. (2007) recorded higher final $\mathrm{pH}$ values in muscles, darker colour of muscles, greater calpastatin (CAST) activity, greater firmness, poor sensory properties and unpleasant taste in cattle that were more excitable. IMMONEN et al. (2000) associated temperament with the concentration of glycogen in the muscles and a higher incidence of DFD meat.

Regarding the quality of baby-beef, the results of our research confirmed that different ages at slaughter, in both young male and female cattle, only produce a negligible effect on $\mathrm{pH}$ and $\mathrm{EC}$ values, as well as meat colour parameters $(\mathrm{P}>0.05)$. The results reported in this study are in line with research conducted by PREZIUSO and RUSSO (2004), who also reported only a modest effect on the $\mathrm{pH}$ value and colorimetric parameters associated with meat of different slaughter age. PLESSIS and HOFFMAN (2007) observed that an increase in slaughter age significantly increased $\mathrm{pH}$ and $\mathrm{a}^{*}$ values, and at the same time significantly reduced the $\mathrm{L}^{*}$ value $(\mathrm{P}<0.05)$, while negligibly increasing the $\mathrm{b}^{*}$ value $(\mathrm{P}>0.05)$. In this study, the increase of slaughter age in young female cattle had only a negligible effect on the quality of the baby-beef meat $(\mathrm{P}>0.05)$. In young male cattle of different slaughter ages, significant differences were only found for the $\mathrm{L}^{*}$ parameter, namely a significant difference was found only between young male cattle slaughtered at the age of 13 to 14 months and the age of 17 to 18 months $(P<0.05)$. We established only a negligible difference between all the other parameters relating to young male cattle $(\mathrm{P}>0.05)$. SARGENTINI et al. (2010) reported that young male cattle of Maremmana breed slaughtered at the age of 24 months showed significantly higher $L^{*}, b^{*}$ and $h^{*}$ values $(\mathrm{P}<0.05)$, as well as negligibly higher $\mathrm{a}^{*}$ and $\mathrm{C}^{*}$ values $(\mathrm{P}>0.05)$ than young male cattle slaughtered at the age of 18 months. MPAKAMA et al. (2014) found that young male cattle at the age of 16 months had higher $\mathrm{a}^{*}$ and $\mathrm{b}^{*}$ values than young cattle at 24 months of age. LAWRIE (1974) associated the observed differences in the colour of meat with variations of intramuscular fat, and concluded that age had no effect on the amount of myoglobin. WULF and WISE (1999) found subcutaneous fat and intramuscular fat (marbling) to be in high positive correlation and reported that, since intramuscular fat is generally white, it can increase the range of $\mathrm{L}^{*}$ values on a scale from 0 (black) to 100 (white). CVRTILA FLECK et al. (2016) considered the quality of meat pertaining to animals that were slaughtered at a later age to be different from the quality of meat pertaining to younger animals and concluded that an increase in age and slaughter weight of animals (most often with ad libitum feeding) results in slower overall growth and an increase in both inter-and intra-muscular fat tissue content that can, in turn, cause a decrease in muscle fibre tenderness and impair the flavour properties of meat. It has 
D. Marenčić et al.: Influence of sex and age on physicochemical properties of baby-beef meat

been reported that all carcasses containing less than $0.76 \mathrm{~cm}$ of subcutaneous fat had both darker meat and a higher $\mathrm{pH}$ value than carcasses containing more than $0.76 \mathrm{~cm}$ of subcutaneous fat (PAGE et al., 2001). The process of ageing meat reduces the ability of myoglobin to bind oxygen in animals and this is the precise reason why, in most cases, older cattle usually have darker meat. The amount of myoglobin in the muscles of younger cattle primarily depends on the breed, sex and type of muscle tissue, and may slightly vary at the level of individual organisms (FAUSTMAN and CASSENS, 1990; STEINHAUSER, 1995). However, on the basis of the results obtained in this study, it could be argued that the age at slaughter of young male and female cattle has only a marginal effect on the colour of meat.

In this study, the highest incidence of DFD meat among young female cattle amounting to $3 \%$, that was found at the age of 12 to 13 months and the age of 16 to 17 months, did not significantly differ from the incidence of DFD at the age of 14 to 15 months $(\mathrm{P}>0.05)$. The highest incidence of DFD meat, amounting to $8 \%$, that was found among young male cattle at the age of 17 to 18 months, did not significantly differ from the incidence of DFD meat recorded for young male cattle slaughtered at the age of 13 to 14 months and young male cattle slaughtered at the age of 14 to 15 months ( $P>0.05)$. MPAKAMA et al. (2014) concede that animals younger than 36 months produce baby-beef of the highest quality and that older animals almost always produce darker meat with a higher $\mathrm{pH}$ value, and show more frequent incidence of DFD meat.

\section{Conclusion}

The results of this study demonstrated that sex had a significant effect on the physicochemical properties of meat $(\mathrm{P}<0.001)$, while the age at slaughter in young male and female cattle had little effect on the physicochemical properties and quality of meat $(\mathrm{P}>0.05)$. The results obtained from this research therefore confirm that the age at slaughter may be increased to up to 18 months in male Simmental cattle, and to up to 17 months in female Simmental cattle, without any significant negative effects on the physicochemical properties and quality of the meat.

\section{References}

ANONYMOUS (2004): Manifest on the quality of beef cattle and half on the slaughter line. Official Gazette No. 20/04.

ANONYMOUS (2005): Manifest on the Conditions and Transport of Animals. Official Gazette No. $116 / 05$.

ALDAI, N., B. E. MURRAY, M. OliVAN, A. MARTINEZ, D. J. TROY, K. OSORO, A. NAJERA (2006): The influence of breed and mh-genotype on carcass conformation, meat physicochemical characteristics, and fatty acid profile of muscle from yearling bulls, Meat Sci. $72,486-495$. 
D. Marenčić et al.: Influence of sex and age on physicochemical properties of baby-beef meat

BYRNE, C. E., D. J. TROY, D. J. BUCKLEY (2000): Post-mortem changes in muscle electrical properties of bovine $\mathrm{m}$. longissimus dorsi and their relationship to meat quality attributes and pH fall. Meat Sci. 54, 23-34.

CVRTILA FLECK, Ž., I. ŽURA ŽAJA, L. KOZAČINSKI, N. POLJIČAK-MILAS, A. SHEKVUGROVEČKI, M. KARDUM, D. MARENČIĆ, H. BRZICA, J. ŠURAN, N. MAČEŠIĆ, B. NJARI, M. ŠIMPRAGA, S. MILINKOVIĆ-TUR (2016): Effects of sex and gonadectomy on quality of pork. Meso 18, 66-73.

ČUBIĆ, E., M. KONJAČIĆ, N. KELAVA, A. IVANKOVIĆ, T. JAKOPOVIĆ (2011): Beef meat colour of different housed Simmental steers and heifers. Proceedings. $46^{\text {th }}$ Croatian and $6^{\text {th }}$ International Symposium on Agriculture, Opatija 833-836.

FAUSTMAN, C., R. G. CASSENS (1990): The biochemical basis for discoloration in fresh meat: A review. J. Muscle Foods 1, 217-243.

FRENCH, P., E. G. O'RIORDAN, F. J. MONAHAN, P. J. CAFFEY, M. T. MOONEY, D. J. TROY, A. P. MOLONEY (2001): The eating quality of meat of steers fed grass and/or concentrates. Meat Sci. 57, 379-386.

HUFF-LONERGAN, E. (2005). Mechanisms of water holding capacity in meat: The role of postmortem biochemical and structural changes. Meat Sci. 71, 194-204.

IMMONEN, K., R. G. KAUFFMAN, D. M. SCHAEFER, E. PUOLANNE (2000): Glycogen concentrations in bovine longissimus dorsi muscle. Meat Sci. 54, 163-167.

LAWRIE, R. A. (1974). Meat science. $2^{\text {nd }}$ ed. Oxford: Pergamon Press.

MARENČIĆ, D., A. IVANKOVIĆ, V. PINTIĆ, N. KELAVA, T. JAKOPOVIĆ (2012): Effect of the transport duration time and season on some physicochemical properties of beef meat. Arch Tierzucht 55, 123-131.

MOJTO, S., K. ZAUJEC, M. GONDEKOVA (2009): Effect of age at slaughter on quality of carcass and meat in cows. Slovak J. Anim. Sci. 42, 34-37.

MONIN, G. (2004). Colour and texture deviation. In: Encyclopedia of Meat Science. (Jensen, W. K., C. Devine, M. Dikeman, Eds). Amsterdam; London: Elsevier Academic Press, pp. 323-330.

MPAKAMA, T., A. Y. CHULAYO, V. MUCHENJE (2014): Bruising in slaughter cattle and its relationship with creatine kinase levels and beef quality as affected by animal related factors. Asian-australasian J. Anim. Sci. 27, 717-725.

MUCHENJE, V., K. DZAMA, M. CHIMONYO, P. E. STRYDOM, A. HUGO, J. G. RAATS (2009): Some biochemical aspects pertaining to beef eating quality and consumer health: A review. Food Chem. 112, 279-289.

MURAMOTO, T., M. SHIBATA, N. NAKANISHI (2003): Effect of slaughter age on beef color stability during display of four muscules from japanese black steers. Asian-Australasian J. Anim. Sci. 16, 1364-1368.

PAGE, J. K., D. M. WULF, T. R. SCHWOTZER (2001): A survey of beef muscle colour and pH. J. Anim. Sci. 79, 678-687.

PLESSIS, I., L. C. HOFFMAN (2007): Effect of slaughter age and breed on the carcass traits and meat quality of beef steers finished on natural pasture in the arid subtropics of South Africa. South African J. Anim. Sci. 37, 143-153. 
D. Marenčić et al.: Influence of sex and age on physicochemical properties of baby-beef meat

PREZIUSO, G., C. RUSSO (2004): Meat quality traits of longissimus thoracis, semitendinosus and triceps brachii muscles from Chianina beef cattle slaughtered at two different ages. Italian J. Anim. Sci. 3, 267-273.

RENAND, G., B. PICARD, C. TOURAILLE, P. BERGE, J. LEPETITE (2001): Relationships between muscle characteristics and meat quality traits of young Charolais bulls. Meat Sci. 59, 49-60.

SARGENTINI, C., R. BOZZI, G. LORENZINI, P. DEGL'INNOCENTI, A. MARTINI, A. GIORGETTI (2010): Productive performances of Maremmana young bulls reared following organic rules and slaughtered at 18 and 24 months of age. Italian J. Anim. Sci. 9, 163-168.

SAS (1999). SAS Software, Sas Institute Inc., Cary, North Carolina, USA.

STEINHAUSER, L. (1995): Hygiena a technologie masa. Steinhausers.r.o, Tišnove. pp. 13-79.

TATUM, J. D. (2006). Pre-harvest cattle management practices for enhancing beef tenderness, Executive Summary. National Cattlemen's Beef Association, Centennial, CO. pp. 1-24.

TATUM, J. D., S. L. GRUBER, B. A. SCHNEIDER (2007): Pre-Harvest factors affecting beef tenderness in heifers. Executive summary, Department of Animal Science, Colorado State University.

VESTERGAARD, M., M. THERKILDSEN, P. HENCKEL, L. R. JENSEN, H. R. ANDERSEN, J. SEJRSEN (2000): Influence of feeding intensity, grazing and finishing feeding on meat and eating quality of young bulls and the relationship between muscle fibre characteristics, fibre fragmentation and meat tenderness. Meat Sci. 54, 187-195.

WULF, D. M., S. F. O’ CONNOR, J. D. TATUM, G. C. SMITH (1997): Using objective measures of muscle color to predict beef longissimus tenderness. J. Anim. Sci. 75, 684-692.

WULF, D. M., J. W. WISE (1999): Measuring muscle colour on beef carcasses using the L*a*b* color space. J. Anim. Sci. 77, 2418-2427.

Received: 20 July 2016

Accepted: 27 June 2017

\section{MARENČIĆ, D., A. IVANKOVIĆ, L. KOZAČINSKI, M. POPOVIĆ, Ž. CVRTILA: Utjecaj spola i klaoničke dobi na fizikalno-kemijska svojstva junećega mesa. Vet. arhiv 88, 101-110, 2018.}

\section{SAŽETAK}

Cilj rada bio je utvrditi utjecaj spola i klaoničke dobi na fizikalno-kemijska svojstva kakvoće mesa simentalske junadi. Istraživanje je provedeno na 1200 jedinki od kojih je 600 bilo muškoga i 600 ženskog spola. Muška junad klana je u starosti od 13 do $14 \mathrm{mj} ., 15$ do $16 \mathrm{mj}$. i 17 do $18 \mathrm{mj}$., dok je ženska junad klana u starosti od 12 do 13 mj., 14 do 15 mj., i 16 do 17 mj. Fizikalno-kemijska svojstva kakvoće mesa (pH, EC i pokazatelji boje mesa) izmjerena su 24 sata post mortem na m. longissimus dorsi. Spol je imao značajan utjecaj na fizikalno-kemijska svojstva kakvoće junećega mesa $(\mathrm{P}<0,001)$, dok je različita klaonička dob imala mali utjecaj na fizikalno-kemijska svojstva kakvoće mesa ( $\mathrm{P}>0,05)$, upućujući na mogućnost povećanja klaoničke dobi kod muške simentalske junadi do $18 \mathrm{mj}$. i kod ženske simentalske junadi do $17 \mathrm{mj}$., bez značajno negativnog utjecaja na fizikalno-kemijska svojstva kakvoće junećega mesa.

Ključne riječi: spol; dob pri klanju; fizikalno-kemijska svojstva; baby-beef 